\title{
Análise temporal e comparação de gravações do excerto orquestral para flauta do Prélude à l'après-midi d'un faune de Claude Debussy
}

\section{André Sinico Cristina Capparelli Gerling}

Resumo: O presente estudo visa analisar alguns aspectos temporais do excerto orquestral para flauta do Prélude à l'après-midi d'un faune de Claude Debussy. Para tal, foram selecionadas dez vídeos de gravações ao vivo de orquestras profissionais europeias no sítio do YouTube. Os quatro primeiros compassos que constituem o solo de flauta foram analisados por meio do Sonic Visualiser e comparados quanto ao andamento, acurácia rítmica e rubato. Como resultados, não encontramos um andamento em comum entre as gravações, porém observamos a utilização pródiga do rubato em contradição à literatura (McCutchan, 1994; Lord, 1998; Buck, 2003; Rodrigues, 2015). Por fim, discutimos também a influência da respiração sob o timing em relação as demais competências técnicointerpretativas como estilo, fraseado e expressividade musical.

Abstract: This text aims at analyzing some of the temporal aspects of Claude Debussy's Prélude à /'après-midi d'un faune orchestral excerpt. To this end, we selected ten vídeo recordings of European orchestras avialable on YouTube. The first four measures of the flute solo were analyzed using the Sonic Visualiser and compared regarding pacing, rhythmic accuracy, and rubato. As a result, there is no standard tempo shared amongst the recordings, we have otherwise detected a liberal use of rubato in contradiction to literature (McCutchan, 1994; Lord, 1998; Buck, 2003; Rodrigues, 2015). Finally, we also discussed the mutual influence of breathing and timing and the relationship between these two aspects in relation to other technical and interpretive skills such as style, phrasing, and musical expressiveness.

O Prélude à l'après-midi d'un faune, poema sinfônico de Claude Debussy (1862-1918) foi composto entre 1891 e 1894 sob encomenda da Societé Nacionale de Musique e este titulo refere-se ao poema 
homônimo de Stéphane Mallarmé (1842-1898) escrito em 1865 e publicado em 1876 em uma edição limitada com ilustrações do pintor impressionista francês Édouard Manet (1832-1883). A respeito do texto de Mallarmé, Piedade (2009) explicou que:

Seu poema coloca-se no gênero de églogue, procurando dar continuidade às éclogas de Virgílio, que, por sua vez, inspiradas nos idílios de Teócrito, inauguram toda uma nova ideia de natureza como lugar de uma beleza nostálgica, o bucólico: trata-se do estilo pastoral (PIEDADE, 2009, p.3).

O autor acrescenta que "na écloga de Mallarmé, o fauno acorda de um sonho no qual era seduzido por ninfas" (Piedade, 2009, p.3).

Ao analisarmos o Prélude à l'après-midi d'un faune de Debussy, constatamos que a instrumentação do poema sinfônico de 110 compassos é composta por flautas (3), oboés (2), corne inglês, clarinetas (2), fagotes (2), trompas (4), harpas (2), e cordas (violinos, violas, violoncelos e contrabaixos). A obra orquestral articula um esquema ternário: $A B A$, que resulta em uma certa inovação ao hesitar o desenvolvimento do tema (Griffiths, 1978, p.9). Assim, o esquema pode ser compreendido como um prelúdio, interlúdio e paráfrase. Debussy não prioriza processos de desenvolvimento motívico no decorrer desta obra, mas confere um destaque especial para o elemento tímbrico. Assim, entendemos que a exposição sob o domínio da flauta se completa no trigéssimo compasso sendo então o discurso musical encaminhado para um interlúdio com predominância das clarinetas, oboés e corne inglês. Esta seção intermediária iniciada por sopros com palhetas se organiza em dois eventos, isto é, compassos de 31 à 51 e de 52 à 76 . No segundo evento, as madeiras, incluindo a flauta, agem de comum acordo, ou seja, em uníssono, sendo que as escolhas de orquestração resultam em um novo ambiente tímbrico. A terceira seção (c.77-110) age como uma paráfrase do início através de modificações 
métricas, de ambiguidades tonais ainda mais pronunciadas e na evocação do motivo inicial.

O compositor apresenta indicações de interpretação, como de praxe, no início da obra: Très modéré, armadura de clave de Mi Maior/Dó\# menor, compasso composto de 9/8, dinâmica piano e as expressões doux et expressif. $\mathrm{O}$ excerto orquestral para flauta do Prélude à l'après-midi d'un faune, um dos mais solicitados em audições para a orquestra em todo o mundo (BUCK, 2003; SILVA, 2014; RODRIGUES, 2015), é constituído pelos trinta primeiros compassos. Nos quatro compassos iniciais, a flauta apresenta a ideia principal, a qual podemos nomear de "tema do fauno" (Figura 1).

Figura 1: Excerto orquestral para flauta do Prélude à l'après-midi d'un faune de Debussy, compassos 1 a 4.

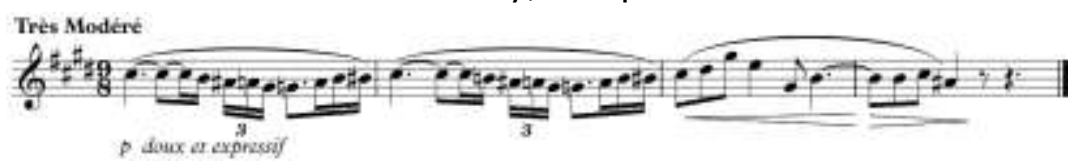

Na primeira parte (c.1-2), a melodia é composta por uma ondulação cromática tendo como notas estruturais o intervalo de trítono (Dó\#5-Sol4), enquanto a segunda parte (c.3-4) desenvolve-se no modo Dórico, mas com a ausência do Fá\#5. No decorrer dos trinta primeiros compassos, o "tema do fauno" é reapresentado total ou parcialmente pela flauta por outras quatro vezes, sendo a primeira delas uma repetição idêntica do solo inicial. Na segunda e quarta vez, a citação do primeiro compasso do solo de flauta amplia-se, o compositor prolonga a duração do Dó\#5 em mais um tempo ao modificar a armadura de compasso para 12/8. Na terceira vez, a métrica é mantida, mas a melodia ocorre transposta à distância de uma $3^{\mathrm{a}}$ Maior descendente. No que diz respeito a este texto, faz-se necessário salientar que nosso foco se volta para o solo de flauta, ou seja, o "tema do fauno" apresentado sem acompanhamento. Estes quatro compassos iniciais se constituem no nosso objeto de estudo tendo em vista o grau de amplitude e 
flexibilidade comumente empregado nas interpretações de flautistas eminentes.

Embora o andamento Très modéré tenha sido estabelecido pelo Claude Debussy, o compositor não especificou uma indicação metronômica. Editores também se mantiveram cautelosos quanto ao oferecimento de sugestões numéricas. A escolha de um tempo básico será então uma decisão a ser tomada pelo flautista, pelo regente caso este decida marcar um tempo no início da execução dos compassos, ou ainda, uma decisão conjunta do flautista e do maestro frente à orquestra. Em qualquer circunstância, a escolha do tempo metronômico poderá influenciar, positiva ou negativamente, certas competências técnico-interpretativas do instrumentista - respiração, afinação, timbre, vibrato, dinâmica, acurácia rítmica/rubato, articulação, estilo, fraseado e expressividade -, principalmente, todas aquelas relacionadas diretamente à respiração.

Na literatura da flauta (McCutchan, 1994; Lord, 1998; Debost, 2002; Buck, 2003; Toff, 2005; Baxtresser, 2008; Toff, 2012; Rodrigues, 2015), comentários e observações sobre a respiração configuram-se como as mais numerosas. Esta ocorrência explica-se porque há uma expectativa que o flautista execute os quatro primeiros compassos em uma única respiração e ao fazê-lo demonstre total controle sobre a respiração, especialmente, em situações de audição, revelando assim um alto grau de competência técnico-interpretativa. No entanto, é intrigante o fato de que Lloyd (apud Lord, 1998) e Baxtresser (2008) ofereçam sugestões de lugares intermediários para o flautista respirar, enquanto Buck (2003) discute estratégias de estudo em relação ao andamento. Em razão disso, podemos ser levados a questionar, em alguns momentos, sobre a real necessidade do flautista executar os quatro primeiros compassos do Prélude à l'après-midi d'un faune de Claude Debussy em uma única respiração em outras situações de performance musical que não a de audição, bem como o fato que isso tenha se tornado uma 
tradição na literatura do instrumento desde 1908 a partir do relato de Moyse (apud McCutchan, 1994).

Por outro lado, não é possível nos distanciar do andamento indicado pelo compositor a fim de não alterar aspectos estilísticos e de expressividade musical. O fato é que essa designação de andamento se refere a um tempo muito moderado ou, tal qual referenciado por Rousseau (1768), como sendo equivalente ao termo italiano “Adagio”, o segundo mais lento dentro as principais gradações de andamento na música. Na literatura do instrumento, Buck (2003) sugeriu que o flautista execute o excerto orquestral em uma marcação metronômica entre 92 a 96 bpm para o valor da colcheia (Buck, 2003, p.45). Ressaltamos que, até o momento, não encontramos outra sugestão que aponte para números metronômicos.

Outro dilema referente a manipulação temporal do solo de flauta do Prélude à l'après-midi d'un faune de Claude Debussy está relacionado a existência de um impasse quanto ao emprego da acurácia rítmica, ou seja a leitura factual das figuras rítmicas ou o uso do rubato, isto é, uma execução rítmica flexível que alonga ou encurta valores. Esse impasse ocorre devido a estrutura rítmica do excerto orquestral nos compassos 1 e 2 . O compositor utiliza-se de recursos de notação para criar o efeito de accelerando e ritardando em torno das notas estruturais - Dó\#5 e Sol4. O resultado entre uma notação e o resultado sonoro nas execuções desta amostra, como veremos adiante, não deixa margem de dúvida quanto à opção pelo emprego liberal do rubato.

Em entrevista publicada na Musical America, Moyse relatou a sua experiência ao executar o Prélude à /'après-midi d'um faune em 1908 sob a regência de Claude Debussy. Moyse comentou que "Debussy [...] exigiu execução rítmica exata" (McCutchan, 1994, p.78). Em corroboração, Rodrigues $(2015$, p.53) trouxe um relato de um dos flautistas explicando que "apesar de ser um solo não se deve tocar livre ritmicamente, sendo importante mostrar as diferenças entre duínas e tercinas". Na Figura 2, podemos observar a célula de aceleração 
composta por uma semicolcheia e uma tercina de semicolcheias, enquanto a célula de desaceleração constituída por três semicolcheias.

Figura 2: Células de aceleração circuladas em verde e células de desaceleração circuladas em vermelho.

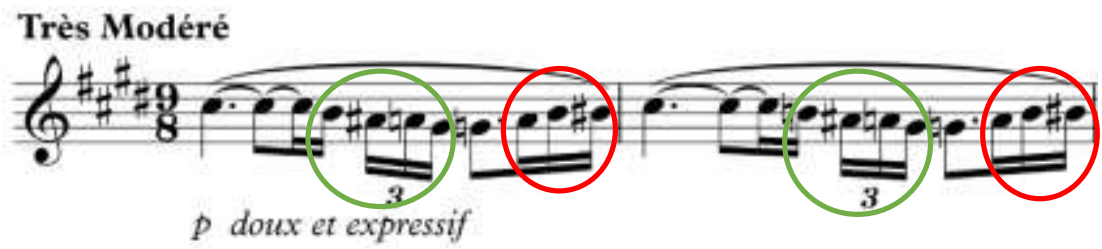

Assim, podemos supor que Debussy no seu rigor com a escrita parece indicar sua opção por exatidão rítmica enquanto que as raras execuções registradas do próprio compositor ao piano mostram o amplo emprego do rubato. A escrita rítmica desse solo de flauta é também um fator importante no afastamento da tonalidade, sendo que o caráter improvisatório afloraria através do respeito aos valores rítmicos. Por isso, ao consultarmos a partitura desta obra orquestral como um todo, não se sobressaem indicações de rubato, por outro lado ocorrem mudanças de andamento e variações, principalmente, por alargamento rítmico do "tema do fauno".

Debost (2002) considera que o Prélude à /'après-midi d'un faune de Claude Debussy proporciona certa liberdade ao flautista na execução mesmo sem qualquer indicação de vocabulário musical que o convide a interpretar este excerto orquestral utilizando-se do rubato. É importante lembrar que esse tipo de discussão polarizava ardorosos debates no início do século XX, quando os intérpretes, ainda ligados ao Romantismo, desrespeitavam a escrita da música impressionista ainda pouco compreendida. Por isso, não podemos negar a persistência dessa ideia romântica também por parte de alguns intérpretes do século $X X$ como a do próprio Michel Debost. Certamente, não podemos ignorar a atenção indispensável quanto à proporção rítmica desse excerto 
orquestral para flauta, visto que o "tema do fauno" será reapresentado outras vezes no decorrer da música, principalmente, com um alargamento rítmico significativo (c.77-80). Ao mesmo tempo, abre-se precedente para o uso do rubato no caso do flautista utilizar a sugestão de respiração intermediária de Baxtresser (2008), entre o Sol4 e o Lá4 no segundo compasso. Esta respiração atua, em alguns casos, ora como um breve ritardando ora como um breve accelerando, mas enseja um prosseguimento mais auspicioso a compleição da melodia.

Nos compassos 3 e 4, a estrutura rítmica é apresentada de forma mais estável. Porém, a utilização de alguns de intervalos como de $4^{\text {a }}$ justa e $6^{a}$ menor pode induzir o uso do rubato em combinação com a expressividade musical almejada. Na Figura 3 , podemos verificar a localização dos intervalos de $4^{\mathrm{a}}$ justa e $6^{\mathrm{a}}$ menor.

Figura 3: Localização dos intervalos mais amplos do solo de flauta, onde o flautista poderia utilizar o rubato como recurso interpretativo.

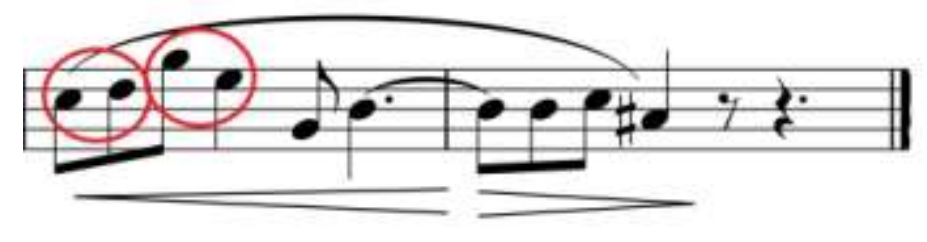

No caso do intervalo de $6^{a}$ menor, o emprego do rubato pode contribuir para uma melhor realização da segunda respiração sugerida por Baxtresser (2008).

Na literatura (McCutchan, 1994; Buck, 2003; Rodrigues, 2015), podemos observar que a principal preocupação dos flautistas profissionais está voltada a questão da proporcionalidade rítmica desse excerto orquestral, visto que o "tema do fauno" é reapresentado posteriormente com um alargamento rítmico e também acompanhado pela orquestra entre notas longas, trêmulos executados pelas cordas e, 
em alguns casos, com arpejos de quintinas ou sextinas pela harpa ocorrentes nos compassos 11-14;21;23; 77-80.

De posse destas considerações, levantamos os seguintes questionamentos: Existe um andamento padrão na interpretação desse excerto orquestral para flauta em gravações de orquestras profissionais? Qual é a variação de andamento entre as gravações e o seu andamento médio? Os flautistas profissionais tendem a respeitar a figuração rítmica? Este aspecto influencia o estabelecimento de um caráter improvisatório? Em que medida a(s) respiração(ções) influenciam o aspecto do timing e a manipulação temporal? Partindo destes questionamentos, o presente estudo visa analisar os aspectos temporais do excerto orquestral para flauta do Prélude à /'après-midi d'un faune de Claude Debussy por meio de comparação de gravações.

\section{Análise de Gravações}

A partir dos anos 1990, houve uma guinada considerável nos recursos considerados relevantes e passíveis de utilização por musicólogos. A "nova musicologia" passou a incluir a análise de gravações como uma das ferramentas mais eficazes para o entendimento das tradições interpretativas. Dentre os musicólogos que propõem o uso das gravações como indispensável, encontram-se trabalhos fundamentais de Bowen (1996), Leech-Wilkinson (2009), Cook (2009, 2013), entre outros. Bowen (1996, p.111) afirma que, "como musicologistas tendemos discutir sobre a partitura como se isso fosse uma obra musical. O autor distinguiu os termos execução musical, partitura e obra musical conforme Ingarden (1986) e explicou que "uma execução musical é um exemplo de uma obra musical enquanto uma partitura é um exemplo qualquer de tradução bruta [...] ou um sumário de uma obra musical" (Bowen, 1996, p.111). Bowen (1996) concluiu que 
"a partitura é apenas uma representação espacial de alguns dos elementos do fenômeno temporal que chamamos de música".

No Brasil, a análise de gravações tem sido agregada às Práticas Interpretativas para estudar gestos musicais (Matschulat, 2011); aspectos de manipulação temporal, expressivos e/ou retórico (Freitas, 2013; Gasques, 2013; Arias, 2014; Yep, 2015; Freitas, Gerling, 2015; Matschulat, 2015). Gerling (2000) aponta que de fato "os intérpretes, frequentemente, se voltarem para a partitura como um meio de responder a questões e apoiar decisões interpretativas" talvez por não se darem conta que atualmente a musicologia, se não abriu mão da musica escrita, pelo menos advoga com veemência a inequívoca relevância da musica como performance (GERLING, 2000, p.1). Valendo-se desta tendência auspiciosa para músicos atuantes, passamos a discorrer sobre a comparação de gravações do excerto orquestral.

Estudos de análise musical por comparação de gravações utilizam software para a sua realização, principalmente, o Sonic Visualizerl. Dentre os aspectos técnico-interpretativos de manipulação temporal encontramos o andamento, acurácia rítmica e rubato, os quais são considerados mais adequados devido a possibilidade de quantificação. Como anteriormente mencionado, Bowen (1996, p.114) ao comentar sobre a variabilidade do tempo nas performances registradas em gravações, destaca o papel de extrema relevância da comparação de obras cujos andamentos sofreram alterações significativas, ora mais rápidos ora mais lentos, porém exibindo manutenção da média no tempo total gravado. Visto isso, propomos aqui a análise de aspectos de manipulação temporal tais como andamento, acurácia rítmica e rubato em decorrência da estrutura fraseológica do solo de flauta e do emprego ou não da respiração intermediária por meio da comparação de gravações do excerto orquestral para flauta do Prélude à l'après-midi d'un faune de Claude Debussy.

1 Software livre desenvolvido pelo Centre for Digital Music da Queen Mary, Universidade de Londres. 


\section{Metodologia}

O material para esta pesquisa foi selecionado a partir de vídeos de gravações realizadas em concertos e disponibilizadas no sítio do YouTube. As palavras-chaves utilizadas foram: "Claude Debussy" e "Prélude à l'après-midi d'un faune" ou "Prelude to the Afternoon of a Faun". Por questões de direitos de transmissão, pudemos incluir somente orquestras da Europa ocidental. A seleção restringiu-se aos vídeos disponíveis no canal da orquestra no YouTube, mas procurou deixar claras as informações sobre o maestro e o flautista solista. No total, 10 vídeos foram selecionados para este estudo, conforme ilustrado na figura abaixo:

Figura 4: Quadro de informações sobre os vídeos do Prélude à l'aprèsmidi d'un faune de Claude Debussy obtidos através do sítio YouTube conforme a orquestra, maestro, flautista e endereço de acesso, respectivamente.

\begin{tabular}{|c|c|c|c|}
\hline ORQUESTRA & MAESTRO & FLAUTISTA & ENDEREÇO \\
\hline $\begin{array}{l}\text { Berliner Philharmoniker } \\
\text { Orchester }\end{array}$ & $\begin{array}{l}\text { Hebert von } \\
\text { Karajan }\end{array}$ & Andreas Blau & https://youtu.be/0EOhDy5MKqE \\
\hline $\begin{array}{l}\text { Berliner Philharmoniker } \\
\text { Orchester }\end{array}$ & Simon Rattle & $\begin{array}{c}\text { Emmanuel } \\
\text { Pahud }\end{array}$ & https://youtu.be/CipRfYTwd0s \\
\hline $\begin{array}{l}\text { Frankfurt HR- } \\
\text { Symphonieorchester }\end{array}$ & $\begin{array}{c}\text { Andres Orozco- } \\
\text { Estrada }\end{array}$ & $\begin{array}{l}\text { Sebastien } \\
\text { Wittiber }\end{array}$ & https://youtu.be/Y9iDOt2WbjY \\
\hline $\begin{array}{l}\text { DR Symfoniorkestret er } \\
\text { Danmarks }\end{array}$ & Ion Marin & Ulla Miilmann & https://youtu.be/kR50WN ydlY \\
\hline $\begin{array}{l}\text { Orchestre de L'Opera } \\
\text { Nacional de Lyon }\end{array}$ & Kazushi Ono & $\begin{array}{c}\text { Julien } \\
\text { Beaudiment }\end{array}$ & https://youtu.be/77UNJfqV6Pc \\
\hline $\begin{array}{l}\text { London Symphony } \\
\text { Orchestra }\end{array}$ & Claudio Abbado & Peter Lloyd & https://youtu.be/AOd2rHWvDlk \\
\hline $\begin{array}{l}\text { London Symphony } \\
\text { Orchestra }\end{array}$ & Valery Gergiev & Alex Jakemann & https://youtu.be/1xK0F5KkfT4 \\
\hline $\begin{array}{l}\text { BBC Scottish Symphony } \\
\text { Orchestra }\end{array}$ & $\begin{array}{l}\text { Donald } \\
\text { Runnicles }\end{array}$ & Ewan Robertson & https://youtu.be/MGJBNbLbfqU \\
\hline $\begin{array}{l}\text { Orchestra } \\
\text { dell'Accademia } \\
\text { Nazionale di Santa } \\
\text { Cecilia }\end{array}$ & $\begin{array}{l}\text { Leonard } \\
\text { Bernstein }\end{array}$ & Angelo Persichilli & https://youtu.be/cL9cfCmTb20 \\
\hline $\begin{array}{l}\text { Orchestra Sinfonica } \\
\text { Nazionale della RAI }\end{array}$ & Georges Prêtre & Gianpaolo Pretto & https://youtu.be/De5Xakact2U \\
\hline
\end{tabular}




\section{Análise de Dados}

Dos vídeos escolhidos com a execução do Prélude à l'après-midi $d$ 'un faune de Debussy, selecionamos orquestras alemãs, dinamarquesa, francesa, inglesa, escocesa e italianas com seus respectivos flautistas solistas (veja Figura 7). Na Figura 5, apresentamos o número de vídeos provenientes de cada um dos países citados.

Figura 5: Número de vídeos provenientes de cada um dos países citados

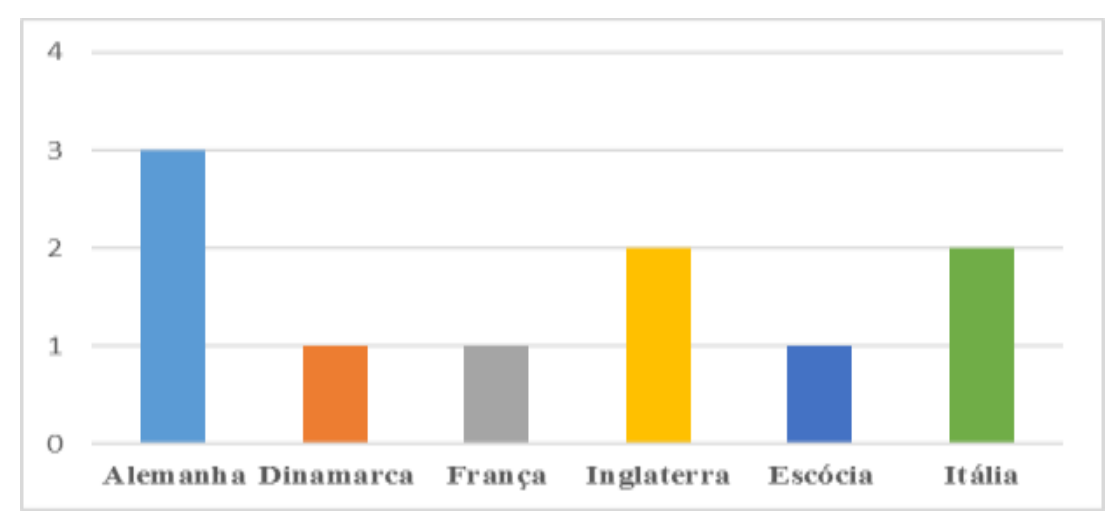

Após a seleção dos vídeos, foi efetuado o download dos mesmos e a conversão dos arquivos de vídeo para áudio (MP3) por meio do programa Free Studio, utilizando a opção - (Lame Insane Quality (320 $\mathrm{Kbits} / \mathrm{s}, 48 \mathrm{kHz}$, Joint Stereo). De posse dos arquivos de áudio em extensão MP3, realizamos a edição dos mesmos reduzindo-os aos quatro primeiros compassos do Prélude à l'après-midi d'un faune de Debussy que constituem o solo de flauta.

A edição foi realizada através do programa de multiplataforma, livre e de código aberto Audacity, versão 2.1.0 para o sistema Windows ${ }^{\circ}$. Na Figura 6, apresentamos um Quadro com a duração de cada áudio com o excerto orquestral, conforme a execução do trecho orquestral pelo flautista, o nome do regente e a presença ou ausência de indicação de andamento no início ou mesmo a marcação de andamento durante o solo de flauta. 
Figura 6: Quadro com a duração de cada áudio com o excerto orquestral, conforme à execução do trecho orquestral pelo flautista.

\begin{tabular}{lccc}
\hline \multicolumn{1}{c}{ FLAUTISTA } & DURAÇÃO & REGENTE & REGÊNCIA \\
\hline Andreas Blau & $20^{\prime \prime}$ & Hebert von Karajan & $*$ \\
\hline Emmanuel Pahud & $24^{\prime \prime}$ & Simon Rattle & $*$ \\
\hline Sebastien Wittiber & $22^{\prime \prime}$ & Andres Orozco-Estrada & Não \\
\hline Ulla Miilmann & $23^{\prime \prime}$ & lon Marin & Sim \\
\hline Julien Beaudiment & $23^{\prime \prime}$ & Kazushi Ono & Sim \\
\hline Peter Lloyd & $21^{\prime \prime}$ & Claudio Abbado & $*$ \\
\hline Alex Jakemann & $25^{\prime \prime}$ & Valery Gergiev & Sim \\
\hline Ewan Robertson & $19^{\prime \prime}$ & Donald Runnicles & Sim \\
\hline Angelo Persichilli & $27^{\prime \prime}$ & Leonard Bernstein & Sim \\
\hline Giampaolo Pretto & $20^{\prime \prime}$ & Georges Prêtre & Não \\
\hline
\end{tabular}

Em duas das gravações há ausência de indicação de andamento ou de marcação do mesmo durante a execução do solo de flauta por parte do regente. No entanto, em três deles (*) não há captura da imagem do regente no vídeo no início da apresentação.

Na Figura 7, ilustramos com gráfico a duração em segundos dos áudios do excerto orquestral para flauta do Prélude à l'après-midi d'un faune de Debussy, conforme a interpretação de cada um dos solistas.

Figura 7: Duração em segundos dos áudios do excerto orquestral para flauta do Prélude à l'après-midi d'un faune de Debussy, conforme a interpretação de cada um dos solistas.

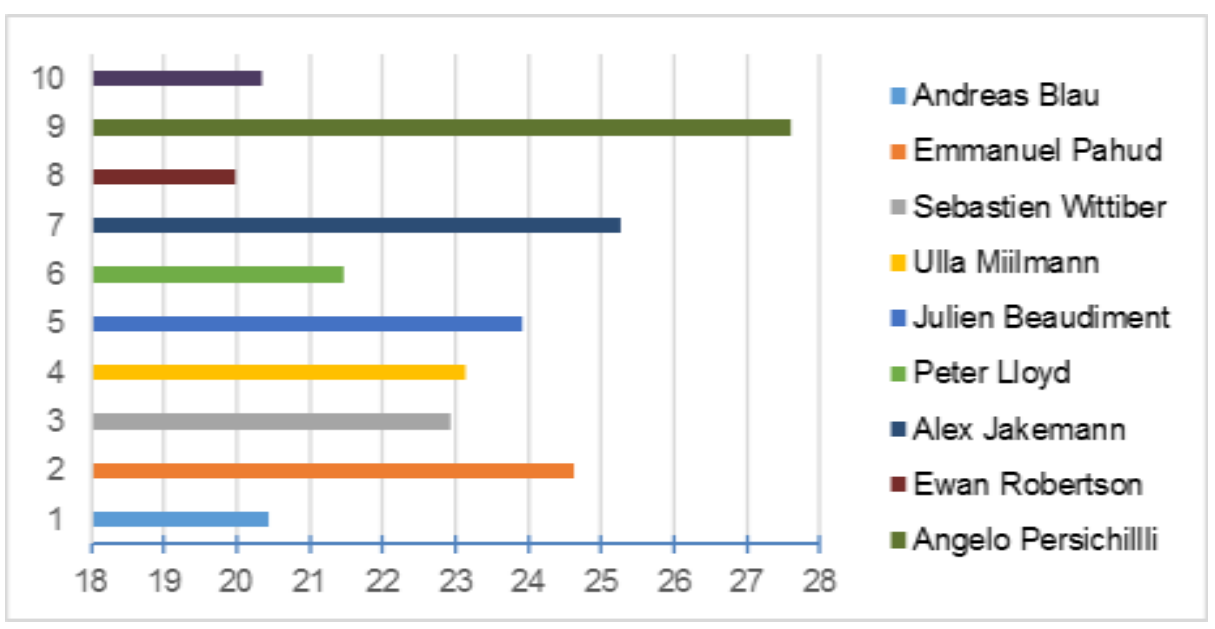


A média de duração dos áudios do solo de flauta é de 22 " segundos, sendo o mais curto de 19" executado pela escocesa Ewan Robertson e o mais longo de 27" interpretado pelo italiano Angelo Persichilli. Na Figura 8, apresentamos a média de duração em relação às durações dos áudios com o excerto orquestral interpretado por cada flautista mencionado.

Figura 8: Média de duração em relação as durações dos áudios com o excerto orquestral interpretado por cada flautista mencionado.

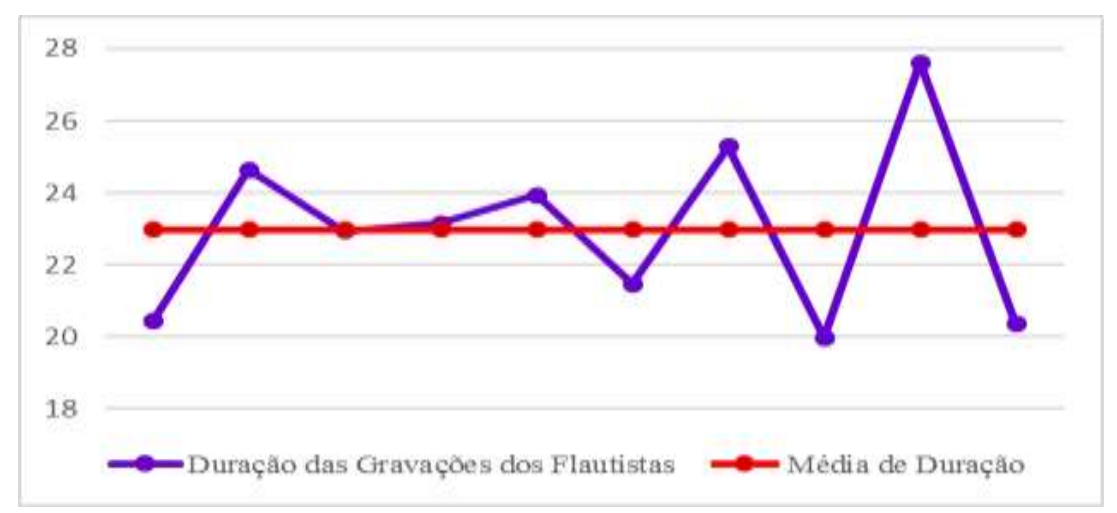

Em seguida, utilizamos o software livre Sonic Visualiser, versão 2.4.1, também para o sistema Windows $^{\circ}$ para analisar o tempo nas execuções do excerto orquestral para flauta do Prélude à l'après-midi d'un faune de Claude Debussy. Os quatro compassos do solo de flauta são constituídos por trinta e duas pulsações de colcheia, conforme a Figura 9 abaixo.

Figura 9: Os quatro compassos do excerto orquestral do Prélude à I'après-midi d'un faune de Claude Debussy constituídos por trinta e duas colcheias.

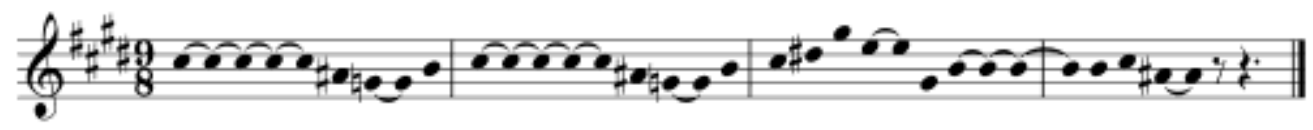

No entanto, devido à entrada de outros instrumentos da orquestra em uníssono na trigésima primeira colcheia, optamos por 
desconsiderar a marcação da trigésima segunda colcheia e, a partir disso, realizamos a análise temporal. Os dados obtidos por meio de análise no Sonic Visualiser foram transferidos para o software Excel da Microsoft Office 2013 para o sistema Windows $^{\circ}$, a fim de construirmos gráficos para a representação da condução do timing da execução do excerto orquestral para flauta do Prélude à l'après-midi d'un faune de Claude Debussy de cada um dos flautistas profissionais.

\section{Andreas Blau}

$\mathrm{Na}$ interpretação de Andreas Blau de 1978, flautista da Berliner Philharmoniker Orchester, sob a regência de Hebert von Karajan, podemos observar a presença de pontos de respiração, conforme Lord (1998) e Baxtresser (2008), isto é, após o Sol4 do segundo compasso (quinto tempo) e antes do segundo Si 4 no quarto compasso (segundo tempo). Na figura a seguir, apresentamos a condução do andamento do solo de flauta interpretado por Andreas Blau.

Figura 10: Condução do andamento do solo de flauta interpretado por Andreas Blau.

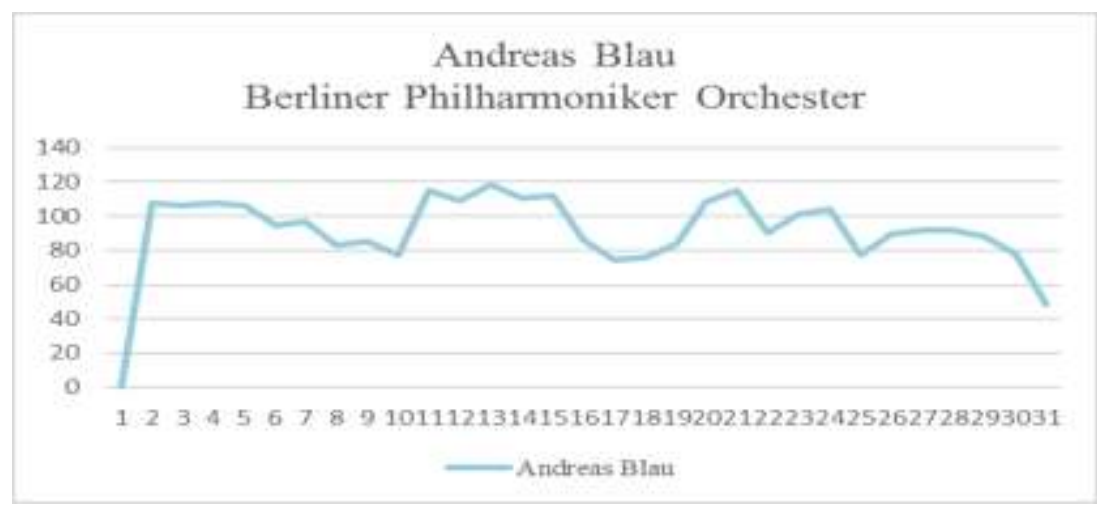

Percebe-se uma leve variação de andamento entre a primeira e quarta colcheias, seguido de um desaceleramento. No segundo compasso, ocorre uma breve recuperação do andamento, um pouco mais 
rápido comparado ao compasso anterior, entre a décima e décima quarta colcheias. Da décima quinta e sétima, observamos um declínio mais acentuado do andamento. $O$ andamento médio da execução de Blau é de $91 \mathrm{bpm}$, sendo o mais lento $48 \mathrm{bpm}$ e mais rápido, 118 bpm. Na Figura 11 , ilustramos o andamento médio em relação à interpretação do flautista alemão e destacamos os seus locais de respiração.

Figura 11: Andamento médio em relação à interpretação do flautista alemão Andreas Blau com destaque para os locais de respiração.

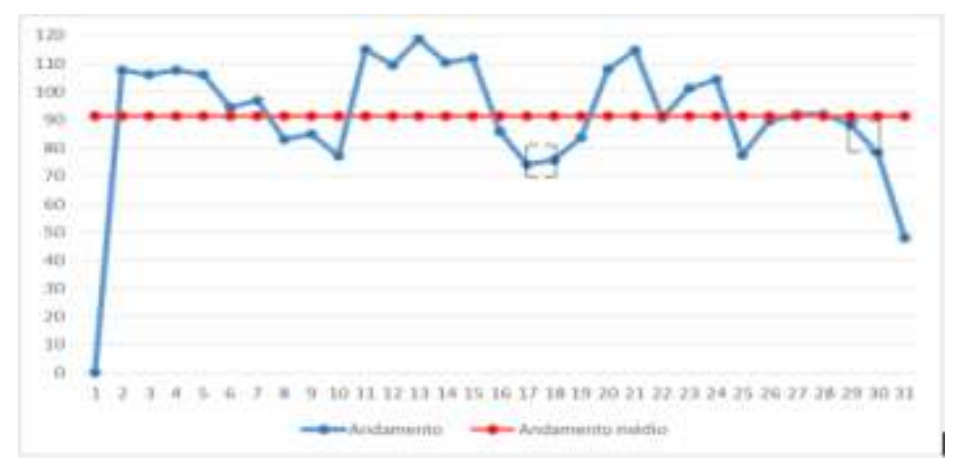

A partir disso, podemos perceber que há um leve acelerando no andamento entre as décimas sétima e oitava colcheias e um desacelerando do andamento entre a vigésima nona e trigésima colcheias, em ambos os casos em pontos que Andreas Blau respirou.

\section{Emmanuel Pahud}

O franco-suíço Emmanuel Pahud, também flautista da Berliner Philharmoniker Orchester, executou o Prélude à I'après-midi d'un faune de Debussy sob a regência de Simon Rattle em 16 de fevereiro de 2012, segundo as informações contidas no vídeo publicado no canal da orquestra no YouTube. Na interpretação de Pahud, observamos uma única respiração localizada após o Sol4 do segundo compasso, de acordo com a sugestão de Baxtresser (2008). A Figura 12 ilustra 
condução do andamento do excerto orquestral para flauta interpretado por Emmanuel Pahud.

Figura 12: Condução do andamento do excerto orquestral para flauta interpretado por Emmanuel Pahud.

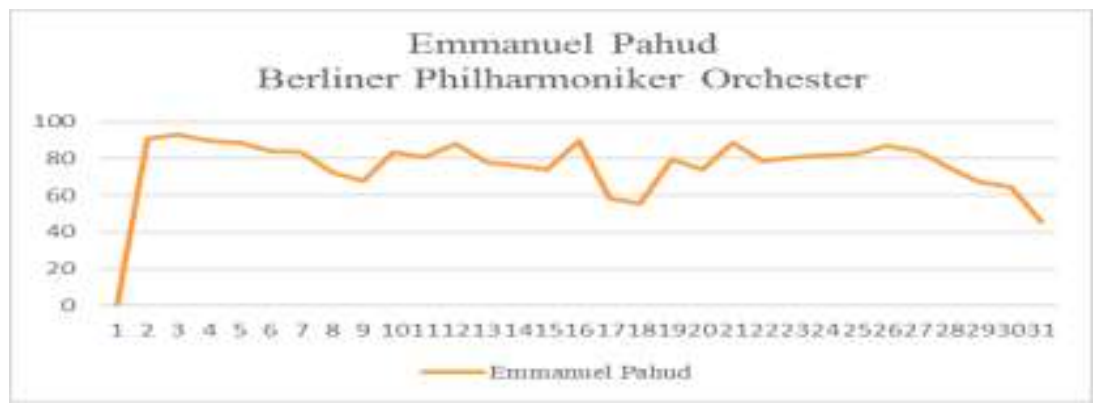

A partir dos dados indicados na figura 12, podemos perceber um desaceleramento do andamento entre a primeira e nona colcheias, enquanto da décima a décima sexta colcheias uma variação do andamento, seguido de um breve desacelerando nas duas últimas colcheias do segundo compasso. O andamento médio da execução de Pahud é de $75 \mathrm{bpm}$, sendo o mais lento $45 \mathrm{bpm}$ e o mais rápido, 92 bpm. A figura 13 ilustra o andamento médio em relação à interpretação do flautista franco-suíço e destacamos o seu local de respiração.

Figura 13: Andamento médio em relação à interpretação do flautista franco-suíço Emmanuel Pahud com destaque para o local de respiração.

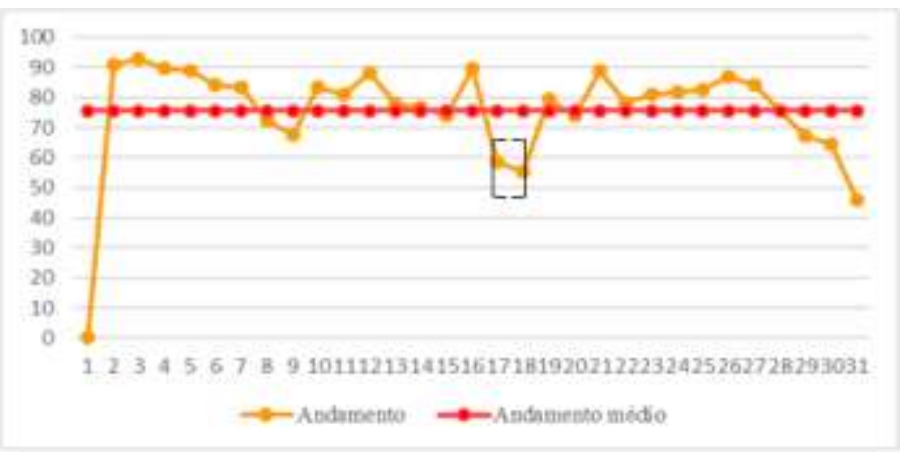


Desse modo, podemos observar que há um leve desacelerando no andamento entre as décimas sétima e oitava colcheias, cujo ponto Emmanuel Pahud respirou

\section{Sebastien Wittiber}

O alemão Sebastien Wittiber, flautista da Frankfurt $H R$ Symphonieorchester, executou o Prélude à l'après-midi d'un faune de Debussy sob a regência de Andrés Orozco-Estrada, em 12 de dezembro de 2014, segundo as informações contidas no vídeo publicado no canal da orquestra no YouTube. Na interpretação de Wittiber, observamos que o solo de flauta foi executado em uma única respiração, segundo McCutchan (1994), Lord (1998), Debost (2002) e Buck (2003). Na Figura 14 , apresentamos a condução do andamento do excerto orquestral para flauta interpretado por Sebastien Wittiber.

Figura 14: Condução do andamento do excerto orquestral para flauta interpretado por Sebastien Wittiber.

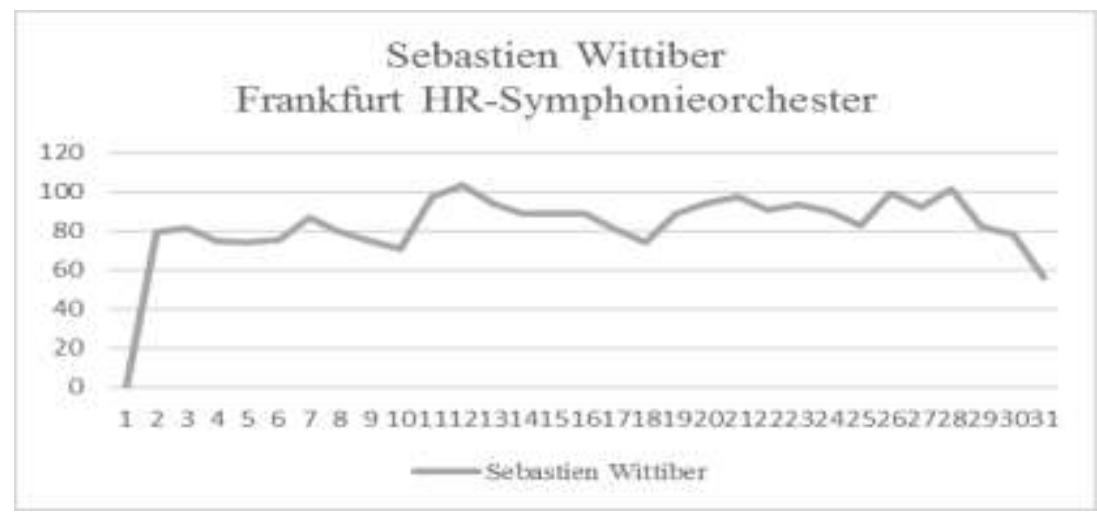

Observa-se uma variação constante de andamento entre a primeira e nona colcheias, seguido de um acelerando entre as décima e décima segunda colcheias e um desaceleramento gradual até a décima oitava colcheia, apesar da ausência de respiração neste local. O andamento médio da execução de Wittiber é de $82 \mathrm{bpm}$, sendo o mais 
lento $56 \mathrm{bpm}$ e o mais rápido, $103 \mathrm{bpm}$. Na figura a seguir, ilustramos o andamento médio em relação à interpretação do flautista alemão Sebastien Wittiber.

Figura 15: Andamento médio em relação à interpretação do flautista alemão Sebastien Wittiber.

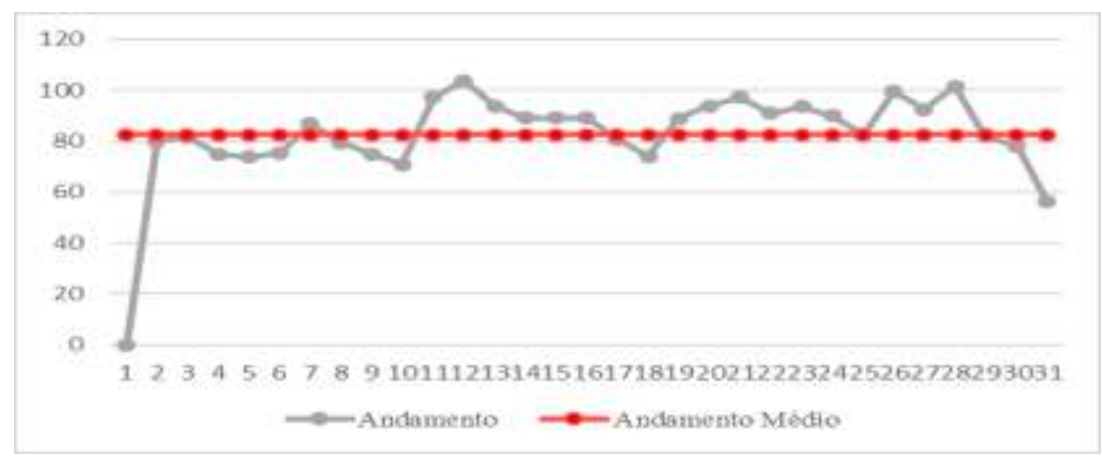

Apesar da ausência de respiração no decorrer do solo de flauta, podemos observar que há um leve desacelerando no andamento entre as décimas sétima e oitava colcheias.

\section{Ulla Miilmann}

A flautista dinamarquesa Ulla Miilmann da DR Symphoniorkestret er Danmarks executou o Prélude à l'après-midi d'un faune de Debussy sob a regência de Ion Marin, sem data, segundo as informações contidas no vídeo publicado no YouTube. Na interpretação de Miilmann, podemos observar que o solo de flauta foi executado em uma única respiração, em concordância com McCutchan (1994), Lord (1998), Debost (2002) e Buck (2003). Na Figura 16, apresentamos a condução do andamento do excerto orquestral para flauta interpretado por Ulla Miilmann. 
Figura 16: Condução do andamento do excerto orquestral para flauta interpretado por Ulla Miilmann.

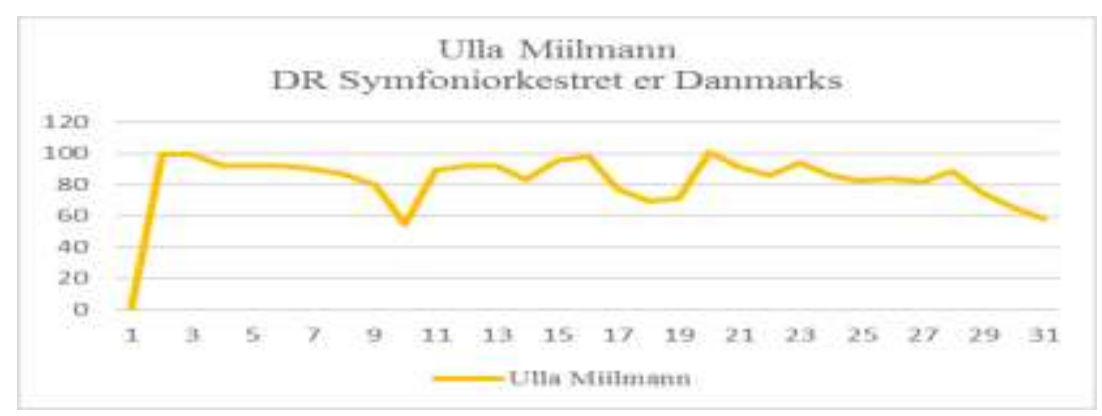

Baseado na Figura 16, podemos observar um declínio progressivo no andamento entre a primeira e a nona colcheias; um desacelerando acentuado entre a nona e décima colcheias, seguida de uma recuperação do andamento entre a décima e décima primeira colcheias. O segundo compasso, isto é, da décima a décima oitava colcheias, percebemos um andamento instável e um declínio do mesmo entre a décima sétima e oitava colcheias, nos tempos de movimentação de duínas e tercinas, mesmo não havendo a presença de respiração. $O$ andamento médio da execução de Miilmann é de $82 \mathrm{bpm}$, sendo o mais lento $58 \mathrm{bpm}$ e o mais rápido, $100 \mathrm{bpm}$. A figura que segue ilustra o andamento médio em relação à interpretação da flautista dinamarquesa Ulla Miilmann.

Figura 17: Andamento médio em relação à interpretação da flautista dinamarquesa Ulla Miilmann.

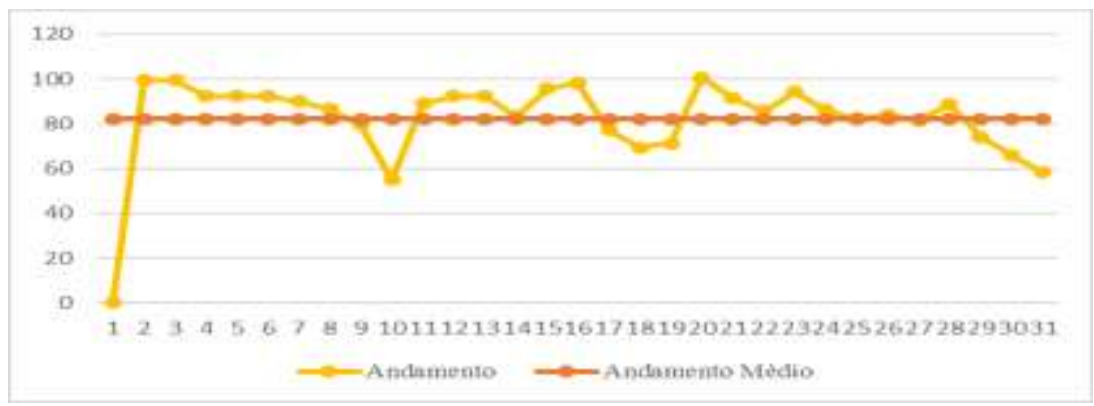


Apesar da ausência de respiração no decorrer do solo de flauta, podemos observar a presença de um desacelerando acentuado no andamento entre a vigésima oitava e a trigésima primeira colcheias, conduzindo para a entrada da orquestra.

\section{Julien Beaudiment}

O flautista francês da Orchestre de L'Opera Nacional de Lyon, Julien Beaudiment executou o Prélude à l'après-midi d'un faune de Debussy sob a regência de Kazushi Ono, sem data, segundo as informações contidas no vídeo publicado no YouTube. Na interpretação de Beaudiment, observamos uma única respiração localizada após o Sol4 do segundo compasso, como a sugestão de Baxtresser (2008). Na Figura 18 , apresentamos a condução do andamento do excerto orquestral para flauta interpretado por Julien Beaudiment.

Figura 18: Condução do andamento do excerto orquestral para flauta interpretado por Julien Beaudiment.

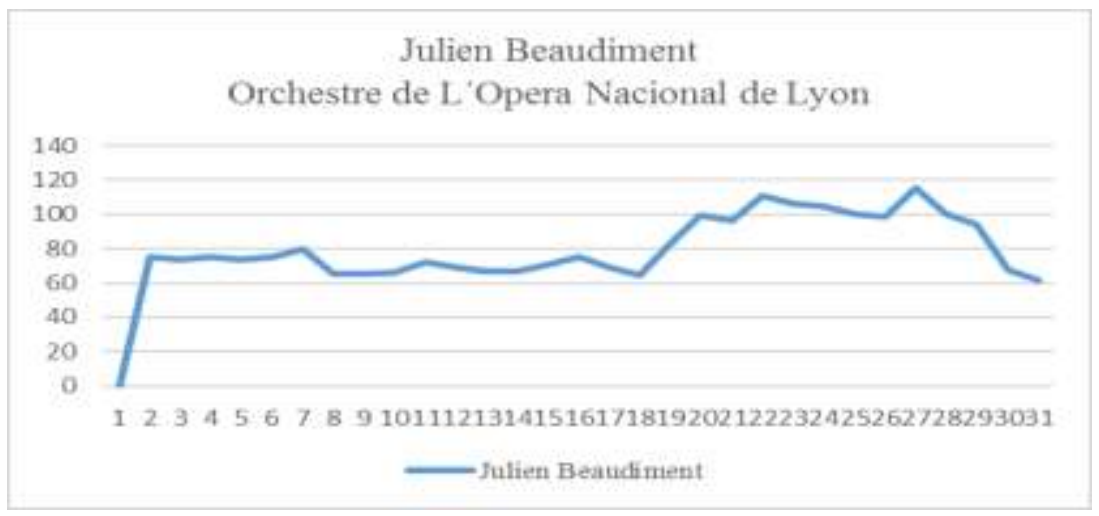

A partir da figura acima, podemos observar uma leve variação de andamento entre a primeira e a décima oitava colcheias que constituem os dois primeiros compassos do solo de flauta. Por outro lado, há a presença de um leve desacelerando entre a décima sétima e oitava 
colcheias, local da respiração de Beaudiment, o qual é perceptível visualmente no vídeo. $\mathrm{O}$ andamento médio da execução do flautista francês é de $78 \mathrm{bpm}$, sendo o mais lento $61 \mathrm{bpm}$ e o mais rápido, 115 bpm. Na Figura 19, ilustramos o andamento médio em relação à interpretação do Julien Beaudiment com a marcação do local de respiração.

Figura 19: Andamento médio em relação à interpretação do Julien Beaudiment com a marcação do local de respiração

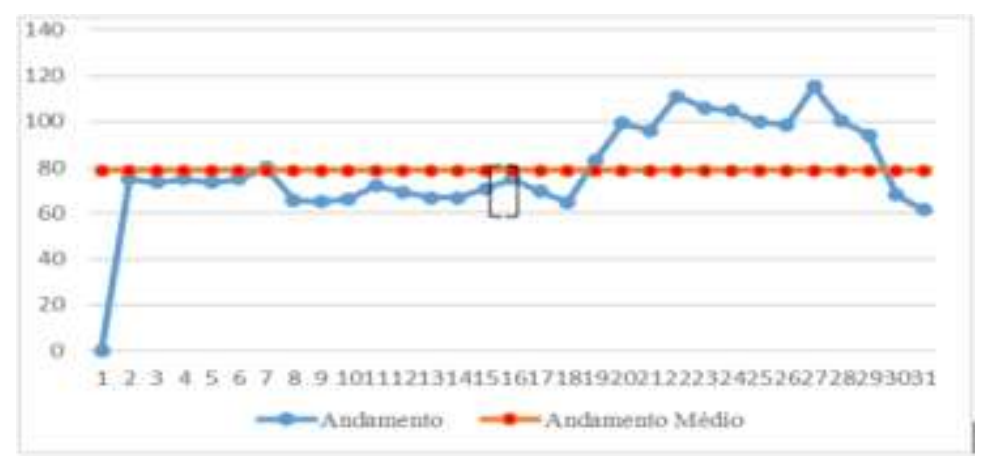

Por último, podemos observar um desacelerando gradual entre a vigésima sétima e trigésima primeira colcheias, como uma forma de preparação para a entrada da orquestra.

\section{Peter Lloyd}

O flautista inglês da London Symphony Orchestra, Peter Lloyd executou o Prélude à I'après-midi d'un faune de Debussy sob a regência de Claudio Abbado, sem data, segundo as informações contidas no vídeo publicado no YouTube. Na interpretação de Lloyd, observamos que o solo de flauta foi executado em uma única respiração, em conformidade com McCutchan (1994), Lord (1998), Debost (2002) e Buck (2003). Na Figura 20, apresentamos a condução do andamento do excerto orquestral para flauta interpretado por Peter Lloyd. 
Figura 20: Condução do andamento do excerto orquestral para flauta interpretado por Peter Lloyd.

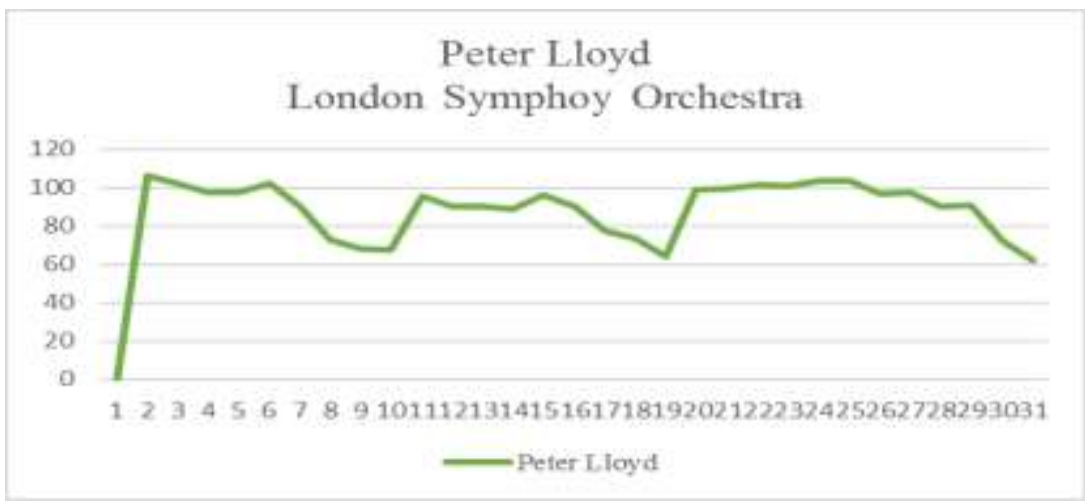

Podemos observar, na figura acima, uma leve variação de andamento entre a primeira e a quinta; a décima e décima quarta colcheias, que se encontram as notas longas de Dó\#5. No entanto, nos tempos de movimentação de duínas e tercinas, há uma desaceleração do andamento causando uma recuperação nas duínas incidentes em intervalos diatônicos, respectivamente as colcheias 8-9; 17-18. O andamento médio da execução de Lloyd é de $86 \mathrm{bpm}$, sendo o mais lento $62 \mathrm{bpm}$ e o mais rápido, $106 \mathrm{bpm}$. Na Figura 21, ilustramos o andamento médio em relação à interpretação do flautista inglês Peter Lloyd.

Figura 21: Andamento médio em relação à interpretação do flautista inglês Peter Lloyd.

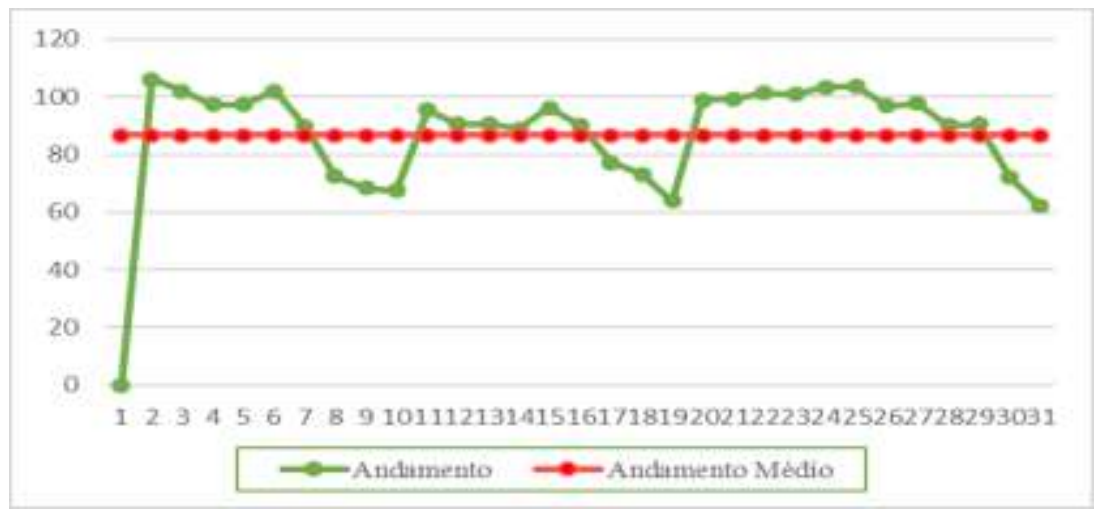


Apesar da ausência de respiração no decorrer do solo de flauta, podemos observar que há um desacelerando acentuado no andamento entre as décimas sétima e nona colcheias, o qual pode ser comparado a trigésima e trigésima primeira colcheias. A interpretação de Peter Lloyd do solo de flauta do Prélude à l'aprés-midi d'un faune de Debussy testifica o seu relato sobre sua execução dado à Lord (1998).

\section{Alex Jakemann}

A flautista inglesa da London Symphony Orchestra, Alex Jakemann executou o Prélude à I'après-midi d'un faune de Debussy sob a regência de Valery Gergiev, em março de 2007, segundo as informações contidas no vídeo publicado no canal da orquestra no YouTube. $\mathrm{Na}$ interpretação de Jakemann, podemos observar a presença de pontos de respiração, de acordo com Lord (1998), isto é, antes do segundo Si4 no quarto compasso (segundo tempo). Na Figura 22, apresentamos a condução do andamento do excerto orquestral para flauta interpretado por Alex Jakemann.

Figura 22: Condução do andamento do excerto orquestral para flauta interpretado por Alex Jakemann.

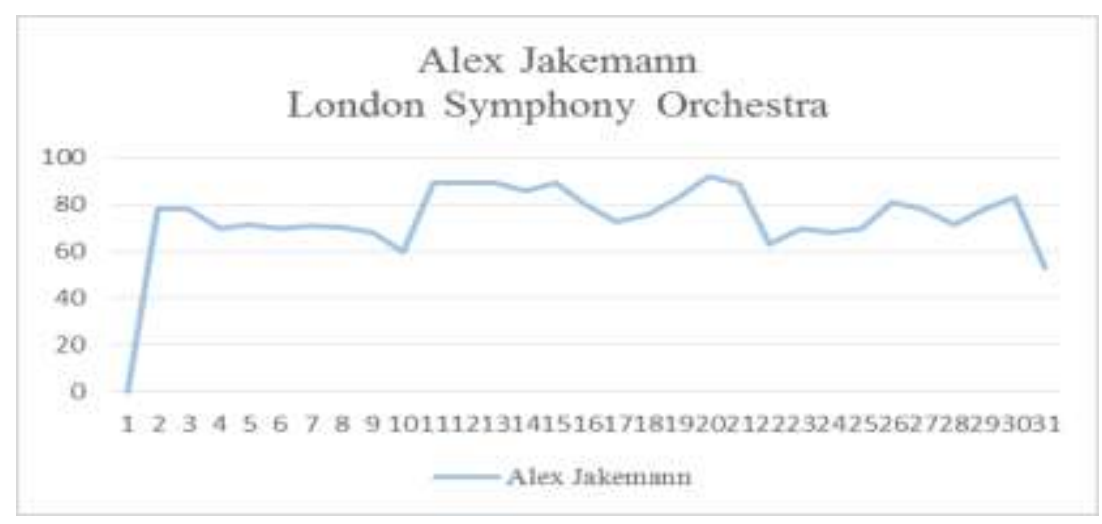


Baseado na Figura 22, podemos perceber uma leve variação no andamento entre as nove primeiras colcheias que consistem em o primeiro inciso da melodia. Quanto as nove colcheias seguintes, que consistem em o segundo compasso, também podemos observar uma leve variação no andamento, porém em um movimento mais marcado. Apesar de não haver a realização da respiração entre as décimas sétima e oitavas colcheias, percebemos um declínio no andamento, seguida de uma retomada do mesmo. O andamento médio da execução de Jakemann é de 78 bpm, sendo o mais lento 53 bpm e o mais rápido, 91 bpm. Na Figura 23, ilustramos o andamento médio em relação à interpretação da flautista inglesa Alex Jakemann.

Figura 23: Andamento médio em relação à interpretação da flautista inglesa Alex Jakemann.

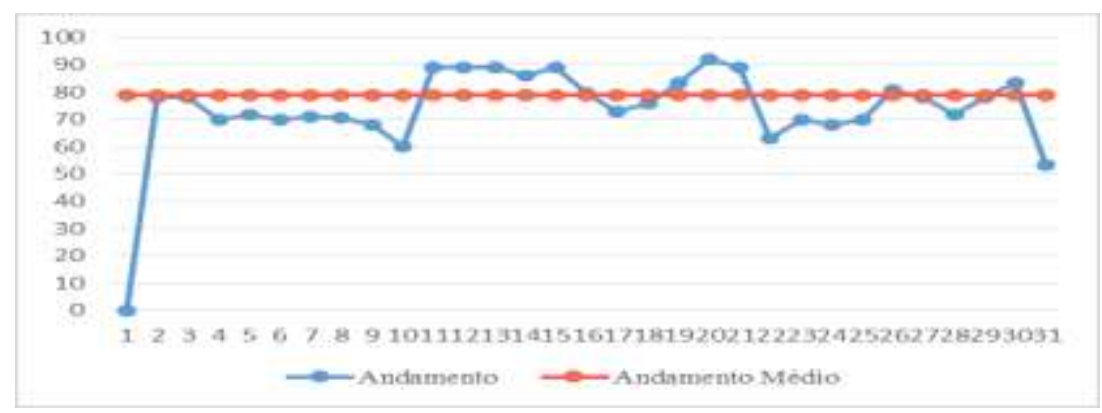

Por fim, podemos observar que há um leve desacelerando no andamento entre as vigésimas sétima e oitava colcheias, cujo ponto Alex Jakemann respirou. Em seguida, ocorre um acelerando, finalizando em um andamento mais lento.

\section{Ewan Robertson}

A flautista da BBC Scottish Symphony Orchestra, Ewan Robertson, executou o Prélude à I'après-midi d'un faune de Debussy sob a regência de Donald Runnicles, em 08 de março de 2011 na Royal Albert 
Hall, segundo as informações contidas no vídeo publicado no YouTube. $\mathrm{Na}$ interpretação de Robertson, observamos que o solo de flauta foi executado em uma única respiração, segundo McCutchan (1994), Lord (1998), Debost (2002) e Buck (2003). Por outro lado, devido aos movimentos dos músculos faciais, temos a impressão que a flautista utiliza a respiração circular para que não haja a interrupção da melodia. Apesar da respiração circular ser uma técnica utilizada por muitos instrumentistas de sopro, Debost (2002) refutou sobre o seu uso na execução do excerto orquestral em questão. Apesar da aparente ausência de respiração, podemos observar um leve declínio do tempo entre a décima sétima e oitava colcheias. Na Figura 24, apresentamos a condução do andamento do excerto orquestral para flauta interpretado por Ewan Robertson.

Figura 24: Condução do andamento do excerto orquestral para flauta interpretado por Ewan Robertson.

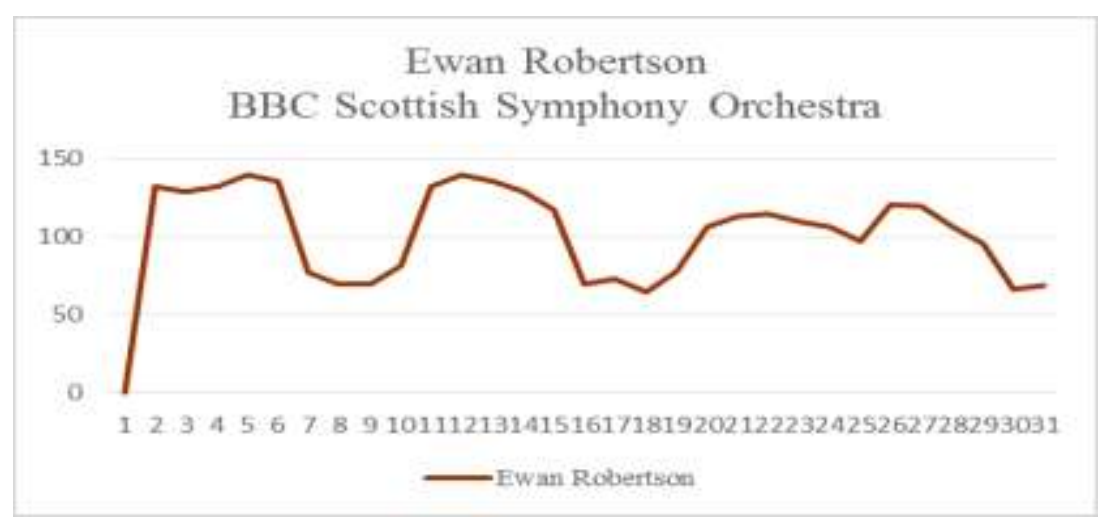

A partir da Figura 24, podemos observar oscilações de timing mais marcadas e localizadas as notas longas do solo de flauta, isto é, nas colcheias 1-5 e 10-14. Por outro lado, nas colcheias localizadas e organizadas como duínas e tercinas, o andamento é mais lento, gerando, em decorrência da amplitude, um gráfico parabólico para as 18 primeiras colcheias. Poderíamos invocar o movimento cicloidal para esta execução de tempos tão variáveis. $O$ andamento médio da execução de 
Robertson é de 101 bpm, sendo o mais lento 66 bpm e o mais rápido, 139 bpm. Na Figura 25, ilustramos o andamento médio em relação à interpretação da flautista escocesa Ewan Robertson.

Figura 25: Andamento médio em relação à interpretação da flautista escocesa Ewan Robertson.

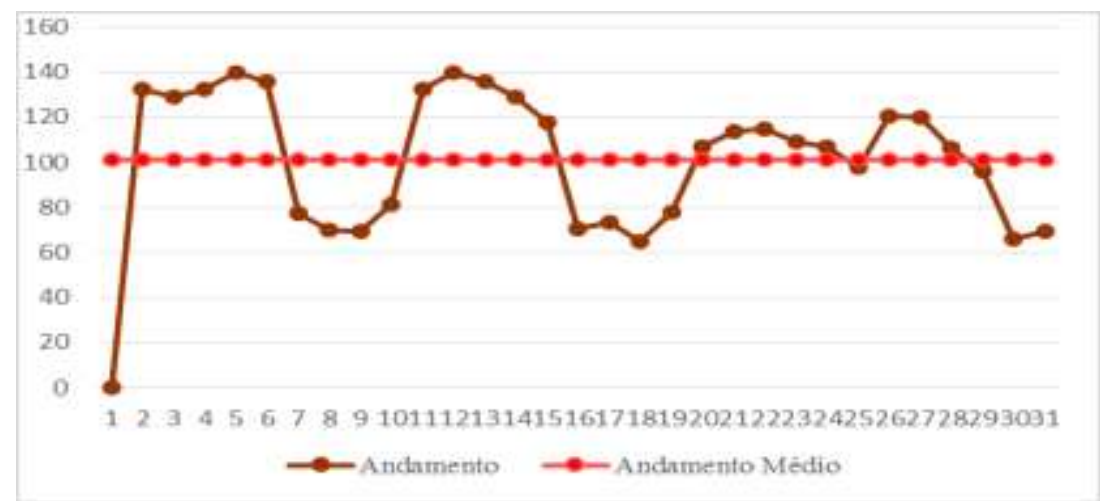

Igualmente, apesar da ausência de respiração no decorrer do solo de flauta, podemos observar que há um leve desacelerando no andamento entre as décimas sétima e oitava colcheias e também entre a vigésima nona e trigésima colcheias.

\section{Angelo Persichilli}

O flautista italiano da Orchestra dell'Accademia Nazionale di Santa Cecilia, Angelo Persichilli executou o Prélude à l'après-midi d'un faune de Debussy sob a regência de Leonard Bernstein, sem data, segundo as informações contidas no vídeo publicado no sítio do YouTube. Na interpretação de Persichilli, observamos que o solo de flauta foi executado em uma única respiração, segundo McCutchan (1994), Lord (1998), Debost (2002) e Buck (2003). Na Figura 26, apresentamos a condução do andamento do excerto orquestral para flauta interpretado por Angelo Persichilli. 
Figura 26: Condução do andamento do excerto orquestral para flauta interpretado por Angelo Persichilli.

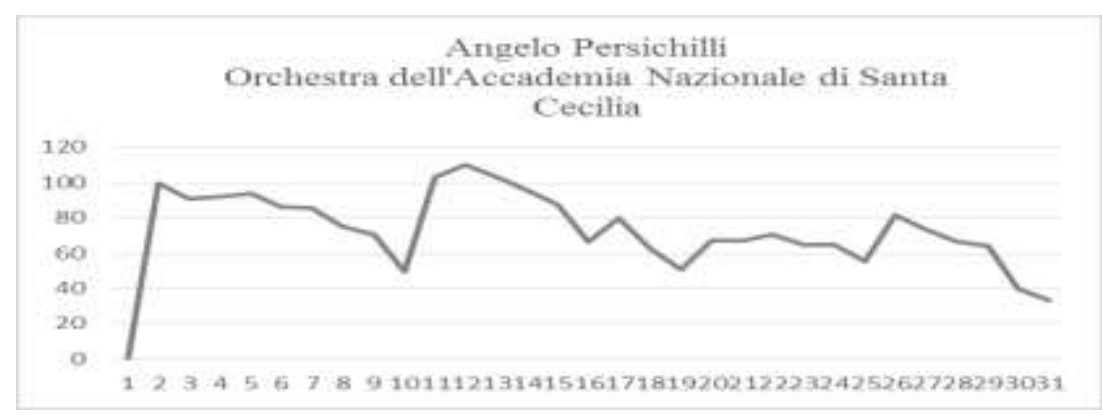

A partir da Figura 26, podemos observar o declínio gradual do andamento ente a primeira e nona colcheias, seguido por um rápido acelerando entre a décima e décima primeira colcheias, retomando o seu declínio até a décima nona colcheia. $O$ andamento médio da execução de Persichilli é de 72 bpm, sendo o mais lento 33 bpm e o mais rápido, 109 bpm. Na Figura 27, ilustramos o andamento médio em relação à interpretação da flautista italiano Angelo Persichilli.

Figura 27: Andamento médio em relação à interpretação da flautista italiano Angelo Persichilli.

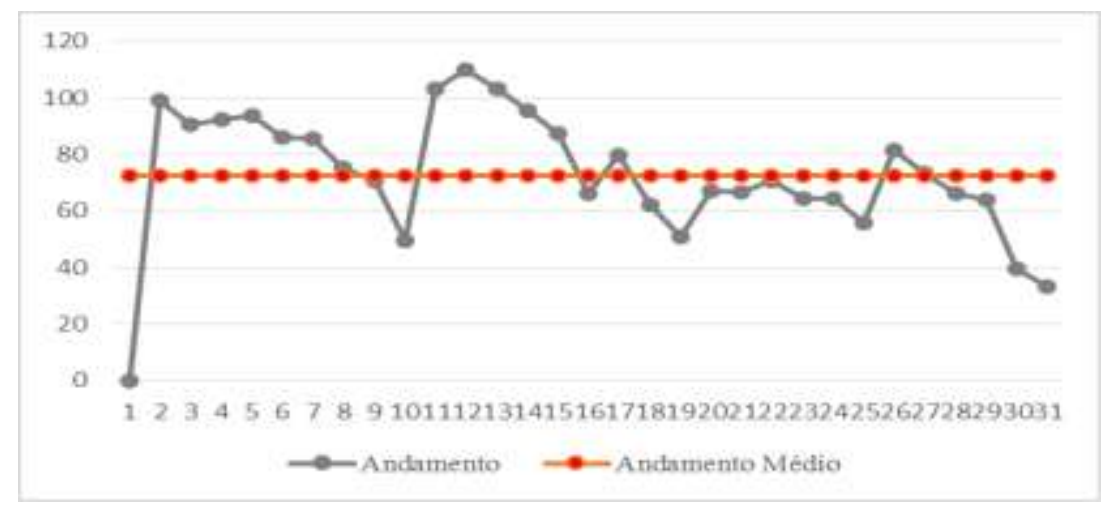

Apesar da ausência de respiração no decorrer do solo de flauta, podemos observar em oposição ao que temos constatado um leve 
acelerando entre as décimas sétima e oitava colcheias. Por outro lado, observamos o desaceleramento recorrente ao final do solo de flauta, embora neste caso ter início na vigésima sétima colcheia.

\section{Giampaolo Pretto}

O flautista italiano, Giampaolo Pretto, da Orchestra Sinfonica Nazionale della RAl, executou o Prélude à l'après-midi d'un faune de Debussy sob a regência de Georges Prêtre, 04 de outubro de 2007, segundo as informações contidas no vídeo publicado no sítio do músico. $\mathrm{Na}$ interpretação de Pretto, observamos que o solo de flauta foi executado em uma única respiração, em concordância com McCutchan (1994), Lord (1998), Debost (2002) e Buck (2003). Apesar da ausência de respiração, podemos observar um leve declínio na intensidade entre a décima sétima e oitava colcheias. Na Figura 28, apresentamos a condução do andamento do excerto orquestral para flauta interpretado por Giampaolo Pretto.

Figura 28: Condução do andamento do excerto orquestral para flauta interpretado por Giampaolo Pretto.

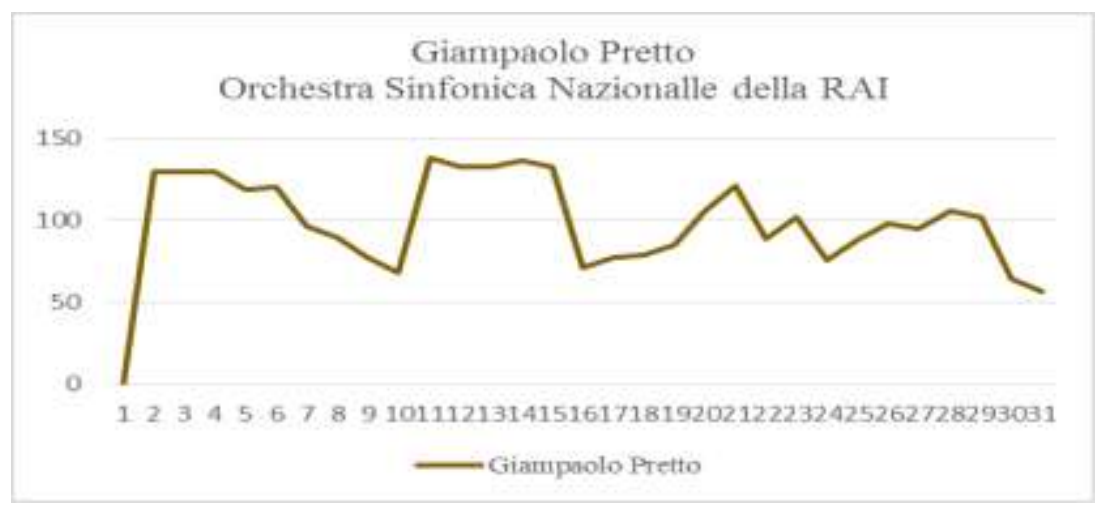


Ao contrário dos outros flautistas, Pretto realiza um leve acelerando entre a décima sétima e oitava colcheias. No entanto, mantem-se o desacelerando ao final do solo. $O$ andamento médio da execução de Robertson é de $98 \mathrm{bpm}$, sendo o mais lento $56 \mathrm{bpm}$ e o mais rápido, $132 \mathrm{bpm}$. Na Figura 29, ilustramos o andamento médio em relação à interpretação do flautista italiano Giampaolo Pretto.

Figura 29: Andamento médio em relação à interpretação do flautista italiano Giampaolo Pretto.

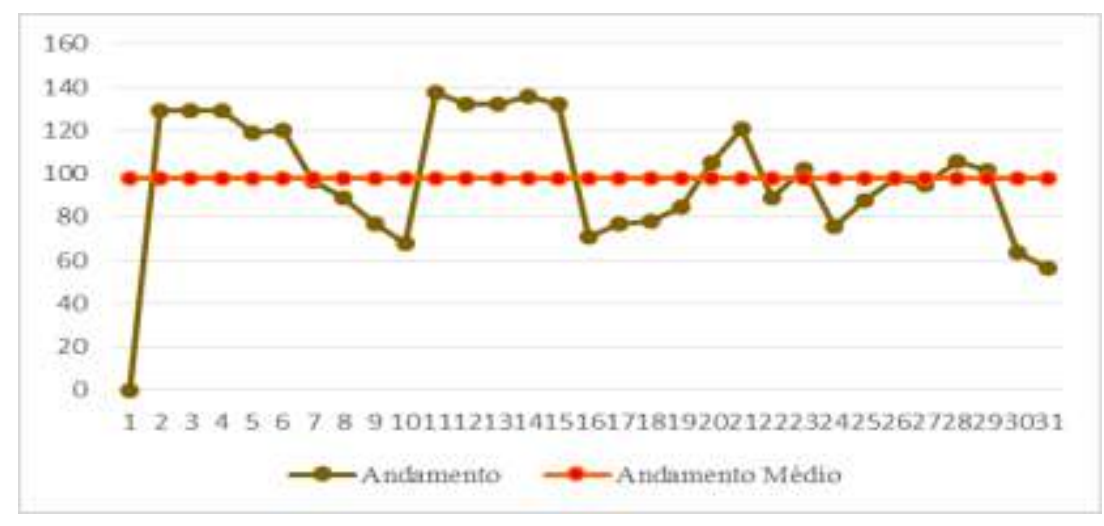

A partir da Figura 29, podemos observar um timing mais elevado, onde estão localizadas as notas longas do solo de flauta, isto é, nas colcheias 1-5 e 10-14. Por outro lado, nas colcheias em que estão localizadas as duínas e as tercinas, o andamento é mais lento, ora de desaceleramento ora de aceleramento.

\section{Discussões}

Como previamente mencionado, o andamento indicado pelo compositor no início da obra Prélude à l'après-midi d'un faune está anotado como Très modéré sem marcação metronômica. Com isto, os intérpretes - flautista, regente ou ainda ambos - escolheram o andamento segundo suas concepções interpretativas. Nesta amostra, os dez flautistas analisados neste texto não mantiveram uma marcação 
metronômica inflexível, ao contrátio, verificamos flutuações significativas na manipulação temporal nos quatro primeiros compassos. De fato, a variação de andamento nas gravações selecionadas foi bastante acentuada e o andamento médio variou entre $75 \mathrm{bpm}$ e 101 bpm, Emmanuel Pahud e Ewan Robertson, respectivamente. As gravações de andamento médio mais próximas ao sugerido por Buck (2003) foram as de Andreas Blau (91 bpm) e Giampaolo Pretto (98 bpm). A média do andamento nesta amostra foi de aproximadamente $84 \mathrm{bpm}$, portanto, abaixo do valor metronômico para a colcheia também sugerido por Buck (2003).

Figura 30: Quadro com a listagem com os flautistas, duração de suas gravações em segundos, variação de andamento e andamento médio em batimentos por minuto (bpm).

\begin{tabular}{lccc}
\multicolumn{1}{c}{ FLAUTISTA } & $\begin{array}{c}\text { DURAÇ̃̃o } \\
\text { (segundos) }\end{array}$ & $\begin{array}{c}\text { VARIAÇÃo DE } \\
\text { ANDAMENTO } \\
\text { (bpm) }\end{array}$ & $\begin{array}{c}\text { ANDAMENTO } \\
\text { MÉDIO } \\
\text { (bpm) }\end{array}$ \\
\hline Andreas Blau & $20^{\prime \prime}$ & $48-118$ & 91 \\
Emmanuel Pahud & $24 "$ & $45-92$ & 75 \\
Sebastien Wittiber & $22^{\prime \prime}$ & $56-103$ & 82 \\
Ulla Miilmann & $23^{\prime \prime}$ & $58-100$ & 82 \\
Julien Beaudiment & $23^{\prime \prime}$ & $61-115$ & 78 \\
Peter Lloyd & $21^{\prime \prime}$ & $62-106$ & 86 \\
Alex Jakemann & $25^{\prime \prime}$ & $53-91$ & 78 \\
\hline Ewan Robertson & $19 "$ & $66-139$ & 101 \\
Angelo Persichilli & $27^{\prime \prime}$ & $33-109$ & 72 \\
\hline Giampaolo Pretto & $20^{\prime \prime}$ & $56-132$ & 98 \\
\hline
\end{tabular}

A análise dos 10 vídeos selecionados para esta pesquisa, nos permitiu observar nitidamente que, em $50 \%$ da amostra o andamento foi indicado pelo maestro frente à orquestra. No entanto, não podemos apontar tendência desta prática quanto a nacionalidade das orquestras ou dos regentes.

Na Figura 31, apresentamos a reunião dos gráficos de condução do andamento do excerto orquestral para flauta do Prélude à l'après- 
midi d'un faune de Claude Debussy de cada um dos flautistas analisados anteriormente.

Figura 31: Reunião dos gráficos de condução do andamento do excerto orquestral para flauta do Prélude à l'après-midi d'un faune de Claude Debussy de cada um dos flautistas analisados anteriormente.

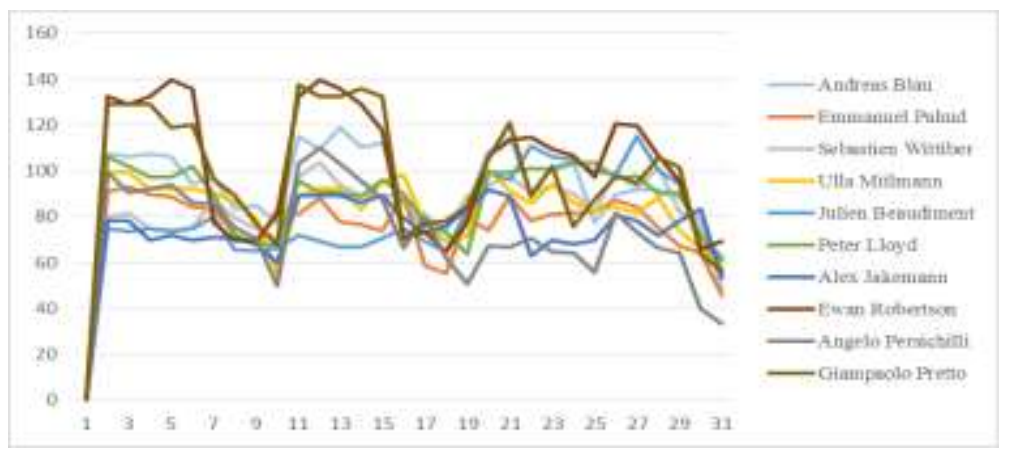

Ao observarmos a Figura acima, podemos afirmar nesta amostra os flautistas profissionais executaram o excerto orquestral do Prélude à I'après-midi d'un faune de Claude Debussy com amplo uso do recurso do rubato, recurso evidenciado justamente nos dois compassos inciais do "tema do fauno". Tal afirmação é evidenciada ao verificamos que os andamentos mais elevados entre a primeira e quinta; décima e décima quinta colcheias se encontram na interpretação de Giampaolo Pretto e Ewan Robertson. Parece haver uma relação significativa entre a flutuação temporal, isto é, o "timing" que caracteriza cada flautista e a caracterização da expressividade implícita na obra.

Em relação a interferência da respiração sob o andamento, constatamos uma desaceleração do andamento entre a décima sétima e oitava colcheias, local sugerido por Baxtresser (2008) para a realização da respiração, mesmo naquelas gravações em que o flautista não respirou, como nos casos de Sebastien Wittiber, Ulla Miilmann, Peter Lloyd, Ewan Robertson e Angelo Persichilli. Por outro lado, Alex Jakemann e Giampaolo Pretto aceleraram levemente o andamento neste 
mesmo ponto, isto é, entre a $17^{\circ}$ e $18^{\circ}$ colcheias. Quanto aos flautistas que respiraram, Emmanuel Pahud e Julien Beaudiment afrouxaram o tempo, enquanto Andreas Blau apressou o andamento nesse mesmo local.

\section{Conclusão}

Ao final da análise temporal do excerto orquestral para flauta do Prélude à l'après-midi d'un faune de Claude Debussy, verificamos não só a impossibilidade de determinarmos um tempo metronômico que traduza o andamento Très modéré impresso na partitura, mas também a inutilidade de buscar esta resposta. Caberá então a cada flautista encontrar o tempo de expressividade que melhor projete seu entendimento do caráter do "tema do fauno". A preocupação dos flautistas profissionais (McCutchan, 1994; Lord, 1998; Buck, 2003; Rodrigues, 2015) quanto a proporção rítmica a ser buscada neste solo de flauta, sendo proporção a palavra-chave, espelha a importância do uso do rubato como ferramenta de expressão artística e individual nos quatro primeiros compassos do excerto orquestral. Variações do timing também podem estar relacionadas à outras competências técnicointerpretativas como o fraseado e a expressividade musical. Nesta amostra pudemos evidenciar através dos gráficos a influência decisiva do controle da respiração no aspecto temporal da performance do excerto orquestral para flauta Prélude à l'après-midi d'un faune de Claude Debussy. Assim, concluimos que a comparação de gravações permite estabelecer semelhanças e contrastes que podem ser incorporados ou não nas nossas atitudes e respostas musicais. 


\section{Referências}

ARIAS, José Luís G. Aspectos Interpretativos no choro "Nosso Choro" de Garoto: uma análise de gravações. Dissertação (Mestrado em Música). Instituto de Artes, Universidade Federal do Rio Grande do Sul, Porto Alegre, 2014.

BAXTRESSER, Jeanne. The Orchestral Excerpts for Flute with Piano Accompaniment. King of Prussia, Pensilvania: Theodore Press, 2008.

BOWEN, José A. Tempo, Durantion, and Flexibility: techniques of analysis of performance. In: Journal of Musicological Research, Vol. 16, 1996, p.111-156.

BUCK, Elizabeth. The Orchestral Flute Audition: An Examination of Preparation Methods and Techniques. Thesis (Doctoral of Musical Arts). Rice University, Houston, 2003.

COOK, Nicholas. Methods for analysing records. In: The Cambridge Companion on Recorded Music. COOK, N., CLARKE, E., LEECH-WILKISON, D., RINK, J. (Ed.), p.221-245, 2009.

. Beyond the score: music as performance. New York: Oxford University Press. 2013.

DEBOST, Michel. The Simple Flute. New York: Oxford University Press, 2002.

FREITAS, Stefanie Grace de Azevedo. Modelagem como estratégia de desenvolvimento de recursos expressivos na performance pianística: três estudos de caso. Tese (Doutorado em Música). Instituto de Artes, Universidade Federal do Rio Grande do Sul, Porto Alegre, 2013.

\& GERLING, C. C. Implicações do processo de modelagem na manipulação de parâmetros temporais e na definição do caráter no Ponteio 46 de Camargo Guarnieri. In: Revista Debates | Rio de Janeiro, n. 14, 225-255, jun. 2015.

GASQUES, Gisela de O. Reflets dans L'eau de Claude Debussy: caminhos interpretativos revelados pela análise de gravações da obra. Dissertação (Mestrado em Artes). Instituto de Artes, Universidade Federal de Uberlândia, Uberlândia, 2013.

GERLING, Fredi V. Performance Analysis and Analysis of Performance: a study of Villa-Lobos's Bachianas Brasileiras $n^{\circ}$ 9. Thesis (Doctoral of Musical Arts). The University of lowa, lowa City, 2000.

GRIFFITHS, Paul. A Música Moderna: uma história concisa de Debussy a Boulez. Rio de Janeiro: Jorge Zahar Ed., 1998. 
LEECH-WILKINSON, Daniel. Recordings and histories of performance style. In: The Cambridge Companion on Recorded Music. COOK, N., CLARKE, E., LEECHWILKISON, D., RINK, J. (Ed.), p.246-262, 2009.

LORD, Suzanne. The Teaching Methods of Peter Lloyd. Dissertation (Doctor of Musical Arts). The Florida State University, Tallahassee, Florida, 1998.

MATCHULAT, Josias. Gestos musicais no Ponteio $n^{\circ} 49$ de Camargo Guarnieri: análise e comparação de gravações. Dissertação (Mestrado em Música). Universidade Federal do Rio Grande do Sul, Porto Alegre, 2011.

--------------. Uma comparação entre duas gravações do Cravo BemTemperado de J. S. Bach por András Schiff. Tese (Doutorado em Música). Universidade Federal do Rio Grande do Sul, Porto Alegre,2015.

McCUTCHAN, Ann. Marcel Moyse: The voice of the flute. Portland: Amadeus Press, 1994.

PIEDADE, Acácio Tadeu de Carmargo. A longa tarde de um fauno. In: DAPesquisa, Florianópolis, n.7, 1-7,01 de julho de 2009.

RODRIGUES, Juliana M. B. Audições Orquestrais para Flauta no Brasil: um estudo sobre estratégias de preparação. Dissertação (Mestrado em Música). Universidade Federal de Minas Gerais, Belo Horizonte, 2015.

TOFF, Nancy. Monarch of the Flute: The Life of Georges Barrère. New York: Oxford University Press, 2005.

. The Flute Book. New York: Oxford University Press, 2012.

YEP, Arturo Sherman. Noche e Huarache de miguel Bernal Jiménez : análises e comparações de gravações baseadas no estudo do andamento e caráter. Dissertação (Mestrado em Música). Universidade Federal do Rio Grande do Sul, Porto Alegre, 2015. 